Volume 6 Issue 2, 2020

P-ISSN : 2460-5697, E-ISSN : 2655-2906

Website: https://www.jurnal-umbuton.ac.id/index.php/Pencerah

\title{
Marginalized Primary Education in Saponda Village, Soropia District, Konawe Regency: Study of Socioeconomic and transportation limitations
}

\author{
1I Ketut Suardika, ${ }^{1}$ La Rabani, ${ }^{1}$ Muliha Halim
}

Email: iketutsuardika@uho.ac.id

\begin{abstract}
This study proposes to contribute information in the form of a description of the limitations of economic and transport affect the marginality of primary education. The research is a qualitative descriptive studywith the location of the study in Saponda Village Soropia District Konawe Regency. The collection of data obtained through interviews, observation and documentation. The data used are primary data obtained directly through the interview process, interviews and secondary data obtained through the village profile Saponda. The results of the study found that the form of economic marginalization community is due to the lack of government attention in efforts to improve the welfare of the community, mostly as traditional small fishermen. Moreover, limited transportation has an impact on the mobility of teachers to Saponda also limited. Besides, the public desire to deliver his son to obtain a decent education outside the village Saponda also limited. Therefore, political governments need to pay more attention to the socio-economy and transportation, especially the Bajo tribe community.
\end{abstract}

Keywords: Primary education; Socioeconomic; Transportation Limitations

\begin{abstract}
Abstrak
Kajian ini bertujuan untuk memberikan informasi dalam bentuk deskripsi mengenai keterbatasan ekonomi dan transportasi berpengaruh terhadap keterpinggiran pendidikan dasar. Jenis penelitian ini adalah penelitian deskriptif kualitatif dengan Lokasi penelitian di Desa Saponda Kecamatan Soropia Kabupaten Konawe. Pengumpulan data diperoleh melalaui wawancara, observasi dan dokumentasi. Jenis data yang digunakan adalah data primer yang diperoleh secara langsung melalui proses wawancara, interveie serta data sekunder diperoleh melalui profil desa Saponda, Hasil kajian diperoleh bahwa bentuk keterpinggiran ekonomi masyarakat dikarenakan kurangnya perhatian pemerintah dalam upaya meningkatkan kesejahteraan masyarakat yang sebagain besar sebagai nelayan kecil tradisional yang tentunya berimbas pada keterbatasan dalam mengakses pendidikan dasar. Serta transportasi yang serba terbatas berdampak pada mobilitas guru ke saponda juga terbatas. Disamping itu keinginan masyarakat untuk mengantarkan anaknya untuk memperoleh pendidikan yang layak di luar desa Saponda juga terbatas
\end{abstract}

Keywords: Pendidikan Dasar; Sosioekonomi; Keterbatasan Transportasi

\footnotetext{
${ }^{1}$ Universitas Halu Oleo, Indonesia
} 


\section{INTRODUCTION}

The success of a development is determined mainly by the progress in establishing the human resources that are closely related to the development of education as a whole, focused and integrated. So that the quality of human resources itself can be harmonized with everything required by the development sector (Ministry of Education and Culture, 1995 ). While education is one of the essential requirements for the manufacture of human and national development. It is indispensable for the development of human resources. School provides the knowledge, skills, and character (Brahmandam \& Bosubabu, 2016). However, improving the quality of human resources in the field of education is still having some problems limitations. These limitations include access to education, facilities and infrastructure, and socioeconomic (Suryanegara \& Nahib, 2015; Latif et al. 2019). Flyn et al. (2011) reported that the experience of students and the possibility of educational success is defined and understood in the context of many influences, including culture, poverty, community, social class, and policies. Another opinion came from Muhammad (2015) which argued that marginalization education affected by the geography and the settlement inhabited by a community or group.

One visible phenomenon is the Bajo community, Saponda Village, Soropia Subdistrict, where the level of social life is still at a relatively low level. (Suardika et al. 2020). The condition of their residential homes characterizes it still use the home stage and the low level of their education. The average level of knowledge of the Bajo tribe stops at the elementary school level, and only a few have education at the junior high level. Bajo tribe, in terms of education level, is still relatively low when compared to other tribes in Southeast Sulawesi, especially the Bajo community who are in
Saponda Village, Soropia District. It caused by several factors such as socioeconomic and infrastructure transportation (Safitri \& Nurmayanti, 2018). As reported by Suardika (2012) that in the village of Saponda outline 90\% populated by Bajo tribe who was still leaving the complexity of the issue so complicated subjects ranging from education, economic, social and infrastructure. Sari et al (2018) in the study suggests that the economic Establishment also give effect to the views of people in light of the importance of formal education. A good community economy can undoubtedly help students in taking formal education in terms of assisting the students to complete their learning facilities and infrastructure so that the learning process can run effectively and efficiently. Economic conditions are significant to be one factor that affects the public's view in responding to the importance of formal education. In addition to the economic problem of society, transportation access Bajo people is significant in supporting the education system.It is because the majority of Bajo people live on the seashore certainly need transportation to go to school. Furthermore, Suardika (2012) said that public facilities that are required by the community to date include boat landing bridges, community transportation to the mainland (the city of Kendari and the capital of the subdistricts). So this condition makes the local population is in a situation of exclusion.

Some of the facts show that nationally, the majority of people have not good primary education. It is on several main factors including inadequate facilities and infrastructure, economic inability to access quality education, geographical factors due to isolated settlements. For this reason, the main task of the government is to support the implementation of 9-year compulsory education (2012). For the 
government, even this problem innovatively creating a new strategic school in remote villages more empowered through various assistance. One of them is the provision of educational facilities, religious guidance, vocational training, and so on nine years of the compulsory program of its recommendation. Still, the application should have the power that can encourage and mobilize community participation. Although the parents who do not heed this program does not get legal sanction, is expected to have an awareness and moral responsibility for the success of this program. Moral responsibility is not solely for their children's education, but it also involves responsibilities as citizens should participate in development. To realize this goal requires a 9-year compulsory cooperation cooperative community participation, especially in motivating families, give their children compulsory. Increasing public participation in the success of a mandatory education program conducted by optimizing the function of the Board of Education, provide aid for the supply of education schools.On the other hand, that in some parts of Indonesia, there are still many communities that desperately need attention, especially on education. They are groups of people who are often referred to by the people "alienated" possessing "fatalism", i.e. low public insight into his mind to reach or plan for their future. This kind of attitude can be seen from the view that success.

Therefore, this issue is exciting to study, especially socio-economic issues and facilities and infrastructure in the form of transportation of the Bajotribs community in Saponda Village, Soropia District. The results of this study are expected to describe information and description of the socio-economic life system and infrastructure (means of transportation) in the village of Saponda, Soropia sub-district that supports the education system in the area.

\section{METHOD}

This study was conducted in Saponda Village, Soropia District, Konawe Regency. The choice of Saponda Village is because the research location is a small island that is inhabited by most Bajo people who depend on the sea, often getting development injustices, so economic conditions are still limited. Besides that, the complexity of social problems in the community in Saponda Village shows some interesting phenomena to be studied in the matter of research, especially social-economic problems and facilities and infrastructure in the form of transportation modes.

This type of research referred to qualitative research with a descriptive qualitative approach. The type of data collected derived from primary data and secondary data that support the validity of the data obtained. Twenty-seven informants consisted of teachers, village heads, community members, community leaders and students. The research instrument consisted of interviews and observations. The problem was analyzed using deconstruction theory which is part of the poststructural approach, that is social fact analysis by trying to dismantle reasoning and government. Development models intended to dismantle social logic in the pattern of community relations in the form of image labelling carried out by other communities in the Bajo tribe community.

\section{DISCUSSION}

\subsection{Limitations of social economic}

Economic conditions for a group of people is a significant factor for their survival and development. The village of Saponda, which is predominantly a Bajo ethnic, works as fishermen, both fishermen and aquaculture, automatically relying on their lives at sea. The Bajo people live their lives by fishing business, using boats that are still simple with 
fishing gear that is still simple so that their yields and income are also limited. This limitation is what causes the people of Saponda village when they go to sea to be intensely dependent on the season, if the conditions of the season are not right, for example, the waves and strong winds; then they decide not to go to sea. In addition to capture fisheries, in this village, there are also aquaculture businesses, for example, seaweed cultivation and sea cucumber business, but are still limited. Seaweed cultivation is better if there is protection, there is a river flow, and the waves are not too hard. For this reason, the condition of Saponda Village (Saponda Island) is not suitable for seaweed cultivation (see figure 1).

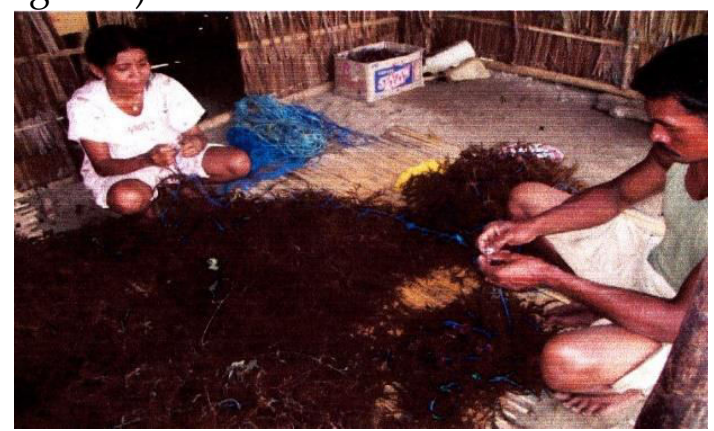

Figure 1. Bajo fishing activities tying sea grass seeds (Source: Personal documents)

In Figure 1, a portion of the community in this village has another business besides fishing, namely seaweed cultivation. This business did not go well because of several obstacles in the form of hard waves and limited community capital. In connection with these conditions and figures, H. Lukman (51 years) said that:

"Government programs that enter the village are more infrastructure procurement, for example, Construction of footpaths, school building assistance, and drinking water distillation, although until now it is not useful because according to the community the water is still salty so it cannot be used anymore. Programs which are in direct contact with the economic development of the community are very lacking" (Interview)

The expression shows that the government's attention in the economic field has the same fate as the education sector, even though these two fields have active links. Associated with economic development there was a program included in Saponda Village (Saponda Island), namely the Coastal Community Economic Empowerment Program through the Department of Fisheries and Maritime Affairs in 2002-2004, but after that, it was not sustainable because the community assisted through the group was also very limited. It was explained by Makmur (61 years) as follows:

"There was a PEMP program in 2002-

2004; this program is quite good.

However, it is not followed up in the form of strengthening the skills of fishermen, such as the group system will run if the business is transparent, a good marketing system, adequate facilities and most importantly clear rules for running in the group, but the reality at that time was the process of group formation, and assistance provided and then released, so it is not sustainable until now "(Interview).

The presentation shows first, the lack of economic improvement programs for the people in this village. Second, the weakness of the program provided is not sustainable and does not refer to the potential of the community. It is relevant to Sondita (2005) who says that coastal community empowerment programs must be carried out holistically, involve the community, refer to the conditions of community poverty indicators and pay attention to the sustainability of the coastal and marine carrying capacity itself

In such a complicated condition, where the community is very limited in knowledge and skills, the threat of abrasion at any time, the threat of a tsunami, the people of the Village of Saponda must be given special attention from the local government. However, the reality is not like that, as explained by Muh. Kadim (Head of UPDT of the SoropiaDiscrit Education Office) said as follows:

"Indeed, I admit that as a representative of the service at the village sub-Regency 
level. There are often significant proposals in every service proposal to the Regency, but always the results are when the budget discussion in the legislator is not covered. It is also normal for children to go to high school to only be able to afford it and the number is very lacking "(Interview)

The expression shows that not only the executive must be responsible and participate in this matter, but also the legislative party as the party that has full rights. In the 2004 Permendagrion the budgeting system, proposals could indeed be made through Musrembang, then SKKPD and through legislator Proposal Rights, but more dominant was the deciding party who had full rights. It has caused the commitment of Konawe local government attention to the Saponda Village community has not been running as it should.

So, the fishermen who was tidying the trawl was one of the fishing gear that he often used. The boat he uses is $2 \times 5$ meters in size but already uses an outboard engine. For this capital, he can earn a living by fishing and trawling with results that are sometimes more, enough and sometimes less. Pak Jali hopes for help from the government, but to date, there has never been any help. In fact, according to him, a larger boat with a large engine also holds the farther capture capacity, considering the current fish population is getting further away so that the catching area is also far away. The following is an excerpt from an interview with Mr Jali (56 years) below:

"This is a boat that I always use, sir, senior high school and of course the length is also not too far because the engine I use is difficult when it is far, and the waves are hard. So I always hope that there is help from the government, but until now there is no. I am sure that if the trawl and we will also get many nets, we will get lots of fish, the income will increase, sir" (Interview)

Mr Jali's expression is a portrait of the conditions felt by most Bajo fishermen today, how this economy is very influential on them, so the efforts to verify the economy are carried out. Efforts to create an alternative economy must be considered by the government because only by increasing the economic income of the people in this place must be balanced by increasing their capacity and skills. From the aspect of education will be influential, the community is increasingly enthusiastic about sending their children to school. Difficulties in looking for fish did not stop there; at certain times, the price of fish dropped dramatically. This condition makes them often losers because not balanced between expenditure with the price of fish obtained. For this reason, some of them are forced to dry the caught fish as a form of survival (see Figure 2).

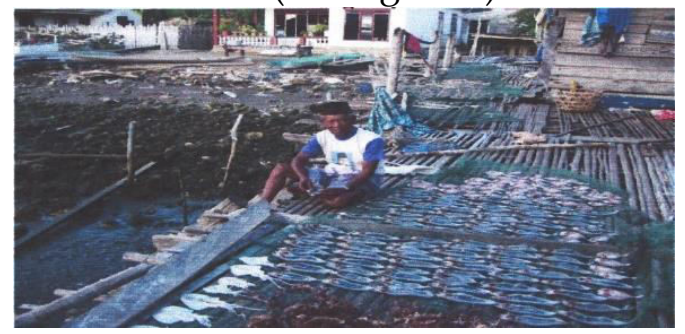

Figure 2. One person named Mr Jali is drying his catch fish (Source: Personal document)

Figure 2 illustrates how difficult it is for them to market their fish, to maintain price stability so that they survive, their catch is dried on simple so that under dry conditions the fish can be sold. The isolated felt by male fishermen, such as Mr Jail, is also inseparable from the isolated felt by mothers of Bajo ethnic fishing families who have a desire to help the family income business, but are constrained by business capital, facilities and access, then they cannot do even more exceptional. As described by Ndoima (43) a Bajo housewife below:

"My job as a housewife that I can do the most is just helping my husband, sir ... prepare to clean the trawl. Sometimes I want to sell, but there is no capital sorry. Well, I am just waiting for the results of the husband alone. Hopefully, there will be a business later so that later I can help my family income ". (Interview) 
The expression above shows that in essence developing a fishermen's business in this village is not so tricky, just developing businesses based on marine or alternative businesses that lead to the development of the home industry of fishermen mothers. During this time, the government and other social change agents pay less attention so that society cannot develop. Different things when holding general elections, regional head elections and presidential elections. Quite many candidates come to visit this place to find and attract sympathy, but after all the processes have taken place, no one will come to pay attention or try to program the community in this area. Hasan (38), one of the teachers who happened to live in Mekar Village, said:

"Dear members of the council, in the past when the candidates wanted to come here often, they promised to pay attention to our problems here but what happened after they entered and were elected as members of the board did not appear again. So it is shocking that for example our proposals, especially the needs of schools, have never been met until now. So it is a pity they forget who chose the brand ". (Interview)

Hasan's experience is enjoyable if at the time the elections and legislative elections often lead the success teams to this village, but after the election moment is over, come to see him just to tell stories never again. This condition clearly shows the lack of attention or reciprocation of the attitude of the people who have provided political support to them both legislative members and regional heads. Forms of discrimination and omission in marginalized conditions continue to occur; this is relevant to the view of Spivak (2003) that the subaltern process occurs because of the dominance of the views and isolated of certain parties in a pluralistic society. Politically, it seems that isolated has occurred by making Bajo ethnic people only as political commodities by making them as second class people. They needed the voice but forgotten because they lost the battle in social life. Economically, the Bajo ethnic community, as well as the general public in this village, still get discriminatory attitudes from the government. The economy is an essential survival of the people in this village, especially the economic situation of the people is very much due to the continuing education of their children.

From the description which has present forms of isolated of the Bajo ethnic community in the village of Saponda found several communities isolated which includes limited access to education. Educational facilities especially supporting the learning process, which is still lacking, the number and quality of teachers is limited. Public transportation and teachers also limited, and community access to economic resources is also minimal. An overall condition is a form and fact where the government has not just and equitably served the educational needs of its people. Law No. 20 of 2003 concerning the National Education System in article 17 on 9-year primary education is an obligation that must be implemented and provided by the government, including facilities and teaching staff.

Unfair treatment, especially when compared to education services in other community groups can give rise to negative perceptions, that in this case shows that a form of community placement such as the Bajo in second or subaltern class groups. Spivak (2003) states that the subaltern form can be seen in terms of treatment, service and relationship patterns. Due to the conventional forms and learning processes carried out by teachers in Saponda Village, this contradicts the concept of critical education, which develops more cooperative learning models and contextual approaches that oriented to the environment and their cultural roots. The uniformity of curriculum, material and approach have taken a form of political culture 
hegemony of power as was done in the new era so that what happens is not a critical awareness education process, but a process of duping and conquest in a power structure of knowledge. In turn, they are far from and alienated from their cultural values, so that the ideology of capitalism is more comfortable to penetrate their mindsets. The Bajo ethnic, which has been very thick with a community that values the environment and tradition, now seems to think more about the material, even the orientation of the school is only for real purposes. If the school is considered unfavourable for their future, then they tend not to be influential in encouraging their children to go to school. This change of thought and ideological construction cannot blame them, but it is the state that should be able to maintain and design education. So that the traditions and cultural values of the Bajo ethnic continue to run in their ideas and behaviour adapted to the development of modern society.

\subsection{Limitations of transportations}

Until now there has been no boat or boat that has become a means of public transportation routinely to facilitate residents in the village of Saponda (Saponda island) by land. The boat used as a means of public transportation when crossing over land has usually been on a fishing boat or community, which sells fish in Kendari City customers, or deliberately they come to Toronipa Village or Mekar Village. So that other communities who want to go ashore or vice versa can ride their boat. This condition made it difficult for Bajo children who wished to continue their studies in the sub regency capital or to the city of Kendari, even though in Saponda village itself the school and facilities were minimal.

The community needs one of the transportation factors because the impact is not only children who want to continue their education outside Saponda but also the educators who want to go to Saponda village have difficulties. As a result of a community does not have the interest to go to school or be lazy for school. It was said by Makmur (Community Leader, 61 Years) as follows:

"The hope that there is public transportation is a common desire here, but this condition has been suggested to the government several times because most of the children who graduate from elementary school do not continue, how is it possible for children to travel outside this island to study outside there if there is no transportation, of course, it's impossible only to expect fishing boats here "(Interview).

It is the same as complained by elementary school teacher SapondaLukman, (51 years) who said that:

"Until now there are still several teachers who teach at Saponda Elementary School who have not settled in Saponda village, so to carry out their duties as a teacher they must PP or every Saturday return, using their boat or riding on a fishing boat. This condition greatly affects the teaching and learning process when the engine or boat is interrupted or damaged so that it can go to Saponda Village because there is no public transportation, so the teaching and learning process also does not go well. What is more the condition of the Saponda elementary education / junior high school still lacks teachers" (Interview)

The quotation shows that sea transportation is currently urgently needed by the people of Saponda Village and communities from outside Saponda Village to make more intensive interactions. Basri (2010) shows that culturally, the Bajo will experience cultural and will progress if there is a more associative reciprocal relationship. It means that if the Bajo people in Saponda Village not supported by the media and means of transportation and social mobility with other communities, hopes for more progress are very difficult. Of course, this condition depends again on the commitment of the government's attention, which until now has not shown 
signs of intense attention to them. Until now, people still rely on fishing boats that travel to Kendari to market their catches. An example of a transport boat that is carried out can be seen in Figure 3.

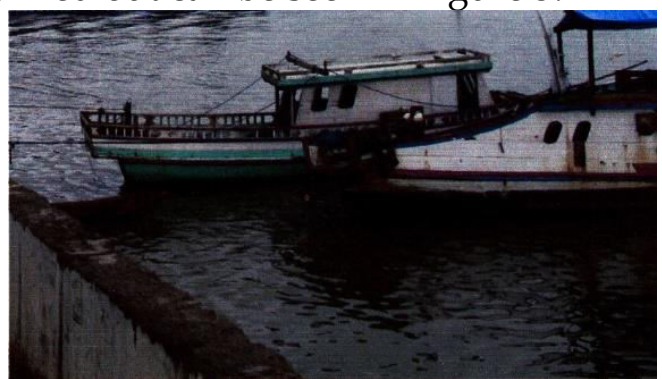

Figure 3. Example of a community outboard boat

(Source: Personal documents)

Figure 3 shows the limitations of transportation that is only owned by certain people. There is no professionally managed transportation as public transportation when mobilizing out. Communities can travel to other villages or the sub regency capital if they get a ride from a boat owner fisherman who will sell their fish.The transportation limitation is also felt by those who are currently honorary teachers of the Saponda Elementary School, who while also teaching are completing their undergraduate studies at the Muhammadiyah University of Kendari. The following is an excerpt from an interview with Marlina (28 years old), one of the Non-permanent tearcher at elementary education Saponda as follows:

"I felt limitations transportation both when I was studying in D2 before, and now Bachelor at the muhammadiyah university of Kendari had to go back and forth to the island of Saponda carry out my duties as a teacher. Even though the lecture is only Friday, Saturday and Sunday, I still feel when I want to go to Kendari or back to Saponda. If you go to Kendari, of course, by riding a fishing boat that brings the fish to the Kendari auction, and vice versa, I am waiting for a fishing boat from Saponda to Kendari only after I board the Saponda boat (Interview)
The same thing was felt by Saponda Elementary School teacher who had to go back and forth to school because until now he lived in Mekar Village (mainland) Hasan (38 years) following.

"Since I was assigned to Saponda Elementary School, I already live in Mekar village because my house is there, so I have to get PP every day, meaning that if my boat is damaged or the engine is damaged, then I cannot carry out teaching duties, then the children are also abandoned. How many times did I ask to move but not granted because of the lack of teacher consideration, but if this is the case, then the learning process also did not go well. Suppose there is alternative transportation, I think it does not matter. If my boat has no disturbance, it does not matter, especially when I take the sea in calm conditions can only take 40-50 minutes "(Interview)

Other Saponda communities also experienced the conditions experienced by Marlina and what was experienced by Lukman. If there is no high enthusiasm from themselves to struggle to continue their education, then the efforts of the community to send their children to school will be difficult to materialize. There are only three Bajo Ethnics who continue their studies to a bachelor. Therefore, the author can take an understanding, that the Saponda Village community also gets marginalized in the form of lack of service needs in the field of transportation, which should be endeavoured and sought to support educational mobility both related to children who want to continue to higher school (senior high school / Institut higher education) or teaching staff on duty in this village.

Thefore, the isolated of the primary education of the Bajo people in Saponda Village are inseparable, and the cultural confinement is less responsive to the development of science and the demands of competition for human life. Apart from the hegemony factor gave birth to resignation and indifference to the position that was addressed to them, 
indeed not inseparable from the unfavourable learning process of their children. For example, schools only waste energy and materials, the ideology of the school's interests only for material mastery (hegemony of materialism), and the principles of their school "that is important to be able to read and write it are considered sufficient". These principles and views are a culture that only brings backwardness continuously. For this reason, efforts are needed by various parties, especially the government and voluntary social groups (NGOs) to carry out the process of counselling, campaigns and awareness of the importance of education. Increasing non-formal and informal education (training), vocation, and the government must balance with educational services to the fullest that is; adequate facilities, learning facilities and teachers. Provide a learning system that is relaxed and fun (no need to wear school uniforms), and more importantly related to teachers is the approach and learning model that adapted to their character and culture as the spirit of multicultural education and transformative critical education.

\section{CONCLUSION}

Based on the description that has been presented so that a conclusion is drawn that the form of socio-economic marginalization of the community is lack of attention from the government in efforts to improve welfare of the community, mostly traditional small fishers and limited transportation impacts on the mobility teachers to Saponda. Besides, the desire for people to deliver their children receives education outside the village Saponda also limited. In addition, the absence of public transportation results in the general public entering and leaving Saponda village, usually riding on fishing boats to the town of Kendari to sell their fish.

\section{REFERENCES}

Basri, A. L. (2010). Kearifan lokal sebagai modal sosial dan budaya dalampperm berdayaan masyarakat pesisir etnik bajo, bungin permai sulawesi tenggara[Local wisdom as social and cultural capital in the empowerment of the Bajo ethnic community, Bungin Permai, Southeast Sulawesi]. Disertasi: PPS Udayana Bali

Brahmanandam, T., \& BosuBabu, T. (2016). Educational status among the scheduled tribes: Issues and challenges. Journal of Politics and Governance, 5(3), 57-66.

Flynn, S., Brown, J., Johnson, A., \& Rodger, S. (2011). Barriers to education for the marginalized adult learner. Alberta Journal of Educational Research, 57(1), 43.

Latif, B., Syaputra, A., Zashkia, N., \& Rusfayanti, R. A. (2019). Society Differentiation, Can Human Rights be Protected?: Critical Study of the Tribes Castration on Community (Case Study of Laporo Buton). Jurnal Magister Hukum Udayana (Udayana Master Law Journal), 8(2), 137-166.

Muhammad, M. (2015). Dampak Permukiman Nelayan terhadap Kehidupan Sosial Ekonomi Budaya Suku Bajo (Kasus Permukiman Nelayan Toronipa Khususnya Masyarakat Suku Bajo di Sulawesi Tenggara). UNITY-Jurnal

Arsitektur, 1(1).

Safitri, A., \& Nurmayanti, N. (2018). Faktor-Faktor yang Mempengaruhi Minat Belajar Masyarakat Bajo. Didaktis: Jurnal Pendidikan dan Ilmu Pengetahuan, 18(3).

Sari, J. M., \& Harudu, L. (2018). Persepsi Masyarakat Nelayan Pesisir Tentang Pentingnya Pendidikan Formal Di Desa Latawe Kecamatan Napano Kusambi Kabupaten Muna Barat. Penelitian Pendidikan Geografi, 3(4). 
Spivak, G. C. (2003). Membaca pemikiran jacques derrida sebuah pengantar [Thought reading jacques derrida an introduction]. Yogyakarta: Penerbit Ar-Ruzz

Sondita, M. Fedi. (2005). Pengelolaan sumber daya kelautan dan perikanan secara terpadu[Integrated management of marine and fisheries resources]. Jakarta: Sekretariat MFCDPBappenas

Suardika, I. K. (2012). Keterpinggiran Pendidikan Dasar dalam Masyarakat Nelayan Suku Bajo Di Desa Saponda Kecamatan Soropia Kabupaten Konawe Provinsi Sulawesi Tenggara. Universitas Udayana

Suardika, I. K., Rusmin, L., Rohmana, R., Anse, L., Harijaty, E., \& Masri, F. A. (2020). Marginalized Primary Education on Ethnic Bajo in Saponda Village, Konawe Regency: Limited Access to Education \& Educators. Universal Journal of Educational Research, 8(6), 2737-2748. doi:10.13189/ujer.2020.080659

Suryanegara, E., \& Nahib, I. (2015). Perubahan Sosial Pada Kehidupan Suku Bajo: Studi Kasus Di Kepulauan Wakatobi, Sulawesi Tenggara. Majalah Ilmiah Globe, 17(1), 67-78. 